\author{
Т. Ю. Лихолат ${ }^{1}$, С. В. Антонюк², В. І. Пробачай ${ }^{2}$ \\ ${ }^{1}$ Дніпропетровський наиіональний університет ім. Олеся Гончара \\ ${ }^{2}$ Дніпропетровський клінічний онкологічний чентр
}

\title{
ОСОБЛИВОСТІ РЕЦЕПТОРНОЇ ВІДПОВІДІ ЧИННИКІВ ЗРОСТАННЯ ПУХЛИНИ У ХВОРИХ НА РАК МОЛОЧНОЇ ЗАЛОЗИ
}

Досліджено особливості рецепторної відповіді факторів росту пухлини у жінок, хворих на рак молочної залози, залежно від віку. Встановлено відмінності рецепторного профілю між первинною пухлиною та метастатазуючим раком тканини молочної залози. Особливо агресивні пухлини, які характеризуються посднанням експресії антигену Кі-67 і надекспресії протоонкогену проліферативного росту Her-2/Neu. У разі подібного посднання визначається гіперрезистентність до лікування.

\author{
Т. Ю. Лихолат ${ }^{1}$, С. В. Антонюк ${ }^{2}$ В. И. Пробачай ${ }^{2}$ \\ ${ }^{1}$ Днепропетровский наииональный университет им. Олеся Гончара \\ ${ }^{2}$ Днепропетровский клинический онкологический центр

\section{ОСОБЕННОСТИ РЕЦЕПТОРНОГО ОТВЕТА ФАКТОРОВ РОСТА ОПУХОЛИ У БОЛЬНЫХ РАКОМ МОЛОЧНОЙ ЖЕЛЕЗЫ}

\begin{abstract}
Исследованы особенности рецепторного ответа факторов роста опухоли у женщин, больных раком молочной железы, в зависимости от возраста. Установлены различия рецепторного профиля между первичной опухолью и метастазирующим раком ткани молочной железы. Особенно агрессивными являются опухоли, в которых сочетается экспрессия антигена Кi-67 и сверхэкспрессия протоонкогена пролиферативного роста Her-2/Neu. В случае подобного сочетания определяется гиперрезистентность к лечению.
\end{abstract}

\author{
T. Y. Lykholat ${ }^{1}$, S. V. Antoniuk ${ }^{2}$, V. I. Probachay ${ }^{2}$ \\ ${ }^{1}$ Oles Honchar Dnipropetrovsk National University \\ ${ }^{2}$ Dnipropetrovsk Clinic Oncological Centre

\section{FEATURES OF RECEPTOR RESPONSE OF TUMOR GROWTH FACTORS IN BREAST CANCER CARRIERS}

Characteristics of the receptor response of tumour growth factors in women with breast cancer varying according to the women's age were investigated. The differences between the receptor profiles of the primary tumour and of the metastatic breast tissue have been found. The tumours characterised by a combination of antigen Ki-67 expression and hyperexpression of proliferative growth proto-oncogene Her-2/Neu are particularly aggressive. In case of such combination the hyperresistance to treatment is determined.

\section{Вступ}

Надзвичайно важливими для вибору науково обгрунтованої терапії хворих на рак молочної залози (РМЗ) $є$ наявність або вірогідність процесів метастазування. Механізми цього процесу при раку молочної залози повністю не відомі. Такими факторами є гетерогенність пухлини, генетична нестабільність пухлинних клітин, локаль- 
не чи системне лікування, часовий інтервал між первинною пухлиною та метастазами, технології визначення рецепторного статусу [7].

Один із факторів, від якого залежить ризик рецидиву раку молочної залози, темп зростання пухлини. Існує декілька методів оцінки цього показника. За останні 20 років найбільш вивченим представником у цій галузі $є$ протоонкоген HER-2/neu (c-erb B-2), який локалізується в 17q-хромосомі та кодує тирозин-кіназний рецептор чинників зростання [6]. Його негативний вплив полягає не тільки у здатності до стимуляції пухлиною свого зростання, а також у залученні строми до експресії рецепторів до самого чинника 3 подальшою «непрямою» індукцією пухлинного зростання (так званий «подвійний» механізм пухлинної прогресіі). Крім того, експресія HER-2/neu відіграє важливішу роль, ніж більшість інших чинників, у прогнозі та термінах виникнення рецидиву у хворих із метастазами [9]. Також надекспресія HER2/neu свідчить про резистентність пухлини до хіміотерапії [5].

Визначення кількості пухлинних клітин, що перебувають у періоді $S$ клітинного циклу, за допомогою проточної цитофлюориметрії - один із найточніших методів оцінки прогнозу зростання пухлини. Досить надійна також непряма оцінка: визначення антигену Ki-67. Антиген Ki-67 - ядерний негістоновий білок, присутній на всіх стадіях клітинного циклу, крім $G_{0}$. У цілому Кі-67 - маркер проліферації клітинних популяцій [8], який дозволяє прогнозувати темп росту пухлини та реакцію пухлини на проведену хіміотерапію [10]. У багатьох недавніх дослідженнях розглянуто потенціал проліферативних маркерів як можливих прогностичних інструментів у пацієнтів із раком молочної залози, але жоден із маркерів не використовується у даний час у клініці для прийняття рішень.

Мета цієї роботи - оцінити залежність сили сигналу рецепторної відповіді факторів зростання пухлини у хворих на рак молочної залози залежно від віку для визначення провідних механізмів проліферативних процесів у тканині молочної залози.

\section{Матеріал і методи досліджень}

Об’єкт досліджень - біоптати тканини молочної залози пацієнток, яким проведене оперативне втручання із приводу онкологічних захворювань органа. Досліджено 350 біоптатів. Визначення ракової патології здійснювали за допомогою бінокулярного світлового мікроскопа.

Оцінка експресії білка Her-2/Neu: до первинних поліклональних антитіл за типом Rabbit відносили Her-2/Neu в концентрації 1 : 1200: при оцінці рівня експресії HER$2 /$ neu враховували різний ступінь фарбування та класифікували від 0 до $3+$.

Експресію рецепторів до епідермального фактора росту Кі-67 обчислювали як середне від кількості мічених ядер на 100 врахованих ядер (при обліку 500-1 000 пухлинних клітин). Якщо у зразку тканини присутні декілька гістологічних картин (ділянка проліферативного ендометрію та проста гіперплазія) - ці ділянки вивчали роздільно.

\section{Результати та їх обговорення}

Рак молочної залози (РМЗ) в нашій країні (як і в усіх промислово розвинутих країнах) - найчастіша злоякісна пухлина у жінок. За частотою захворюваності рак молочної залози вийшов на перше місце, випередивши не тільки рак шийки матки, а i рак шлунка, рак легень та інші пухлини, що зустрічаються у жінок та чоловіків. Захворюваність на РМЗ має два піки: перший припадає на вікову групу 40-45 років, другий - після 50-55 років. Для оцінки та прогнозу перебігу РМЗ використовують традиційні критерії: розмір пухлини, форму та темп іiі росту, локалізацію в молочній 
залозі, наявність регіонарних і віддалених метастазів, гістологічний тип і ступінь диференціації. Останнім часом велика увага приділяється біологічній агресивності РM3, що складається з багатьох чинників, зокрема, експресії рецепторів до естрогенів і прогестеронів і епідермальних факторів росту [1-4].

Для визначення провідних механізмів проліферативних процесів у тканині молочної залози проведено оцінку сили сигналу рецепторної відповіді чинників зростання пухлини за наявності метастазів порівняно з неметастазуючими пухлинами залежно від віку пацієнтів.

Рецептори епідермального фактора росту Her-2 - важливі фармацевтичні мішені при лікуванні пацієнтів із метастазуючим раком молочної залози. HER-2-neu локалізується на мембранах клітин i, після зв'язування з лігандами, активує кінази, а ініційована внутрішня тирозинкіназа конформативно зміненого рецептора запускає реакції фосфорилювання білків, що беруть участь у передачі мітогенних сигналів [6]. Його негативний вплив полягає не тільки у здатності до стимуляції пухлиною свого зростання, а також у залученні строми до експресії рецепторів до самого чинника із подальшою «непрямою» індукцією пухлинного зростання (так званий «подвійний» механізм пухлинної прогресії). Крім того, експресія HER-2/neu відіграє важливішу роль, ніж більшість інших чинників у прогнозі та термінах виникнення рецидиву у хворих із метастазами. При позитивному HER-2/neu-статусі 5-річна виживаність складає $56 \%$, при негативному - $73 \%$; за наявності метастазів ці показники складають $33 \%$ і $62 \%$, відповідно [7]. Також надекспресія HER-2/neu свідчить про резистентність пухлини до хіміотерапії.

У групі жінок віком 40-50 років, хворих на рак молочної залози, у яких не відмічене метастазування пухлини, відповідь Her-2/Neu силою $0,1+$ зафіксована у $81 \%$ випадків, сила відповіді $2+$ спостерігалась у $3 \%, 3+-16 \%$ пацієнтів (рис. $a$ ).

Для групи, яку склали хворі, що мали метастази пухлини, експресія Her-2/Neu силою $0,1+$ відмічена у $81 \%$ хворих, $3+-$ у $16 \%$ обстежених пацієнтів. Жінки 3 онкопатологією молочної залози, у яких сила відповіді за Her-2/Neu становила $2+$, до проаналізованої сукупності не входили (табл. 1).

Таблиия 1

Рівень фактора епідермального росту Неr-2/Neu у біоптатах молочної залози жінок, хворих на рак молочної залози, $\boldsymbol{n}(\%)$

\begin{tabular}{|c|c|c|c|c|}
\hline \multirow{2}{*}{$\begin{array}{c}\text { Діапазон } \\
\text { вимірів }\end{array}$} & \multicolumn{2}{|c|}{ Хворі без метастазів, $n(\%)$} & \multicolumn{2}{|c|}{ Хворі з метастазами, $n(\%)$} \\
\cline { 2 - 5 } & $40-50$ років & старші 50 років & $40-50$ років & старші 50 років \\
\hline $0,1+$ & $46(81)$ & $162(86)$ & $6(81)$ & $36(86)$ \\
\hline $2+$ & $2(3)$ & $0(0)$ & $0(0)$ & $3(7)$ \\
\hline $3+$ & $9(16)$ & $26(14)$ & $1(16)$ & $3(7)$ \\
\hline
\end{tabular}

Фактор зростання пухлини Кi-67 дозволяє прогнозувати темп росту та реакцію пухлини на проведену хіміотерапію [9]. Антиген Кi-67 так само є незалежним прогностичним фактором відносно рецидивування у хворих із поверхневими формами. Так, на основі метааналізу 46 досліджень показано, що пацієнти, пухлини яких були позитивними за Ki-67, мали можливість більш важких рецидивів і гіршого виживання: у пацієнтів із Ki-67-позитивною пухлиною відзначалося збільшення ризику рецидиву на 93 \% та ризику смерті - на 95 \% порівняно з пацієнтами з Кі-67-негативними пухлинами. Проведений метааналіз підтверджує предикторну роль Кі-67 для ранніх стадій раку молочної залози, показуючи істотну асоціацію між експресією маркера та ризиком рецидиву та смерті в усіх популяціях, розглянутих для обох випадків. 


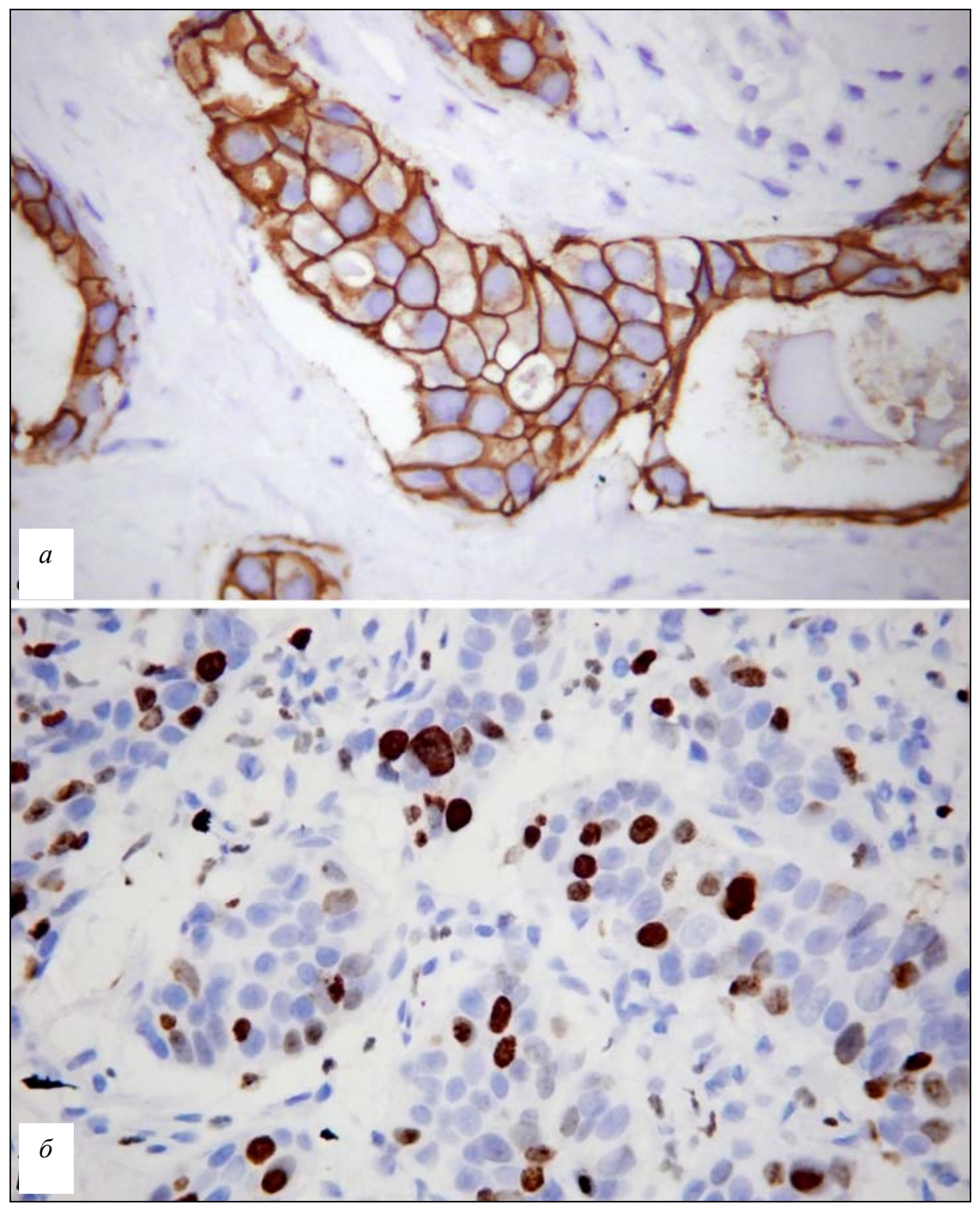

Рис. Імуногістохімічна характеристика раку молочної залози: $a-\mathrm{Her}-2 / \mathrm{Neu}(3+), \mathrm{x} 400 ; \sigma-\mathrm{Ki}-67$ раку молочної залози, негативного за Her-2/Neu (3+), x 400; імунопероксидазний метод

За рівнем вмісту Ki-67 у групі віком 40-50 років, що мали метастази пухлин молочної залози, рівень сигналу в діапазоні 0-30 відмічений у 75 \% жінок, сигнал у межах $31-$ 60 відзначений у $25 \%$ випадків. Відповіді в діапазоні 61-100 не спостерігалися.

У цій же віковій групі онкохворих, що не мали метастазів, сигнал у межах 0-30 був у 48,5 \%, у діапазоні 31-60 - у 51,5 \% обстежених. У межах сили сигналу 61-100 відповідь була відсутня (табл. 2).

У 86 \% хворих на РМЗ віком 50 років і старших, що не мали метастазів, детермінована сила відповіді за Her-2/Neu $0,1+, 3+-14$ \% обстежених. Не зафіксовано випадків експресії Her-2/Neu силою $2+$. Експресія Her-2/Neu силою 0, 1 + визначена у 86 \% пацієнтів старшої вікової групи, пухлини яких метастазували. Екс- 
пресія силою $2+$ зафіксована у 7 \% випадків, 3 - також у 7 \% досліджених зразків (див. табл. 1).

За рівнем Кі-67 у групі пацієнтів, старших 50 років, із метастазами в діапазоні 0-30 рівень сигналу був у $78 \%$ жінок (рис. $1 b$ ). Сила відповіді в межах 31-60 зафіксована у $18 \%$ онкохворих. $4 \%$ жінок із метастазуючим РМЗ мали відповідь у діапазоні від 61-100.

Табличя 2

Рівень Кі-67 антигену у біоптатах молочної залози жінок, хворих на рак молочної залози, $\boldsymbol{n}(\%)$

\begin{tabular}{|c|c|c|c|c|}
\hline \multirow{2}{*}{$\begin{array}{c}\text { Діапазон } \\
\text { вимірів }\end{array}$} & \multicolumn{2}{|c|}{ Хворі без метастазів, $\mathrm{n}(\%)$} & \multicolumn{2}{|c|}{ Хворі з метастазами, $\mathrm{n}(\%)$} \\
\cline { 2 - 5 } & $40-50$ років & старші 50 років & $40-50$ років & старші 50 років \\
\hline $0-30$ & $17(48,5)$ & $43(60,5)$ & $3(75,0)$ & $18(78,0)$ \\
\hline $31-60$ & $18(51,5)$ & $25(35,0)$ & $1(25,0)$ & $4(18,0)$ \\
\hline $61-100$ & $0(0,0)$ & $3(4,5)$ & $0(0,0)$ & $1(4,0)$ \\
\hline
\end{tabular}

У старшій віковій групі жінок із неметастазуючим РМЗ хімічний сигнал у межах від 0 до 30 спостерігався у 60,5\%. У діапазоні 31-60 відповідь відмічена у $35 \%$ біоптатів. У межах сили сигналу 61-100 відповідь була у 4,5 \% хворих (див. табл. 2).

\section{Висновки}

1. Із віком ризик захворювання на пухлини молочної залози зростає, що $\epsilon$ наслідком порушення гормонального профілю як в організмі жінки в цілому, так і локально-регіонального стероїдного статусу.

2. Не знайдено вірогідної різниці між змінами експресії антигену HER-2/neu y пацієнтів із пременопаузальним i постменопаузальним РМЗ, що свідчить про можливість застосування цього показника для оцінки та прогнозу перебігу захворювання незалежно від віку пацієнтів.

3. Відмічені зміни рецепторного профілю між первинною пухлиною та метастазуючим раком тканини молочної залози. При метастазуючих пухлинах дискоординація рецепторів проонкогену проліферативного росту Her-2/Neu може відбуватися у двох напрямах, однак альтерація у більшості випадків проявлялася зниженням позитивності рецепторного статусу.

4. Проліферативний маркер Ki-67 допомагає оцінити прогноз у пацієнтів із ранніми стадіями раку молочної залози. Із віком концентрація антигену Кi-67 збільшується, що свідчить про імовірність рецидивів у хворих. У той же час експресія Ki-67 сама по собі не настільки небезпечна, оскільки у людей похилого віку знижується активність метаболізму. Набагато небезпечнішим $є$ той феномен, коли експресія антигену Ki-67 прямо корелює з надекспресією протоонкогену проліферативного росту. У випадку подібного сполучення визначається гіперрезистентність до лікування.

\section{Бібліографічні посилання}

1. Грибач С. М. Клініко-біологічні особливості перебігу раку молочної залози у хворих похилого віку / С. М. Грибач, Н. В. Бородай, В. Ф. Чехун // Онкологія. - 2011. - Т. 13, № 4 (50). C. $260-265$.

2. Деякі фактори ризику розвитку раку молочної залози й прогнозу плину захворювання в пацієнток з України / С. П. Довженко, Х. Рассі, Л. М. Захарцева та ін. // Лік. справа. - 2007. № 7. - C. 61-64.

3. Значение прогностических факторов опухоли в выборе тактики лечения больных раком молочной железы / И. Е. Седаков, В. Н. Смирнов, Д. В. Полищук, Т. Л. Скочиляс // Новоутворення. -2010 . - № 5. - С. 56-61.

42 
4. Лихолат Т. Ю. Иммуногистохимические исследования в диагностике рака молочной железы / Т. Ю. Лихолат, С. В. Антонюк, Н. О. Кравцова // Актуальні питання сучасної медицини: Тези конф. - Харків, 2011. - С. 106-108.

5. Bankfalvi A. HER-2 diagnostics // Mag. Onkol. - 2008. - Vol. 46, N 1. - P. 11-15.

6. Clinical relevance of Her-2 amplification and overexpression in human cancers / F. J. Esteva, L. Pusztai, W. F. Symmans et al. // Ref. Gynecol. Obstet. - 2000. - Vol. 7. - P. 267-276.

7. Howard E. M. Correlation and expression of p53, HER-2, vascular endothelial growth factor (VEGF), and e-cadherin in a high-risk breast-cancer population // Int. J. Clin. Oncol. - 2004. - Vol. 9, N 3. - P. 154-160.

8. Prognostic significance of $\mathrm{p} 53$, bcl-2 and Ki-67 in high risk superficial bladder cancer / N. E. Stavropoulos, I. Filiadis, E. Ioachim et al. // Anticancer Res. - 2002. - Vol. 22 (6B). - P. 3759-3764.

9. Repeated observation of breast tumor subtypes in independent gene expression data sets / T. Sorlie, R. Tibshirani, J. Parker et al. // Proc. Nat. Acad. Sci. USA. - 2003. - Vol. 100. - P. 8418-8423.

10. The role of $\mathrm{bcl}-2, \mathrm{p} 53$, and $\mathrm{Ki}-67$ index in predicting tumor recurrens for low grade superficial transitional cell bladder carcinoma / T. T. Wu, J. H. Chen, Y. H. Lee, J. K. Huang // J. Urol. - 2000. Vol. 163, N 3. - P. 758-760.

Надійшла до редколегії 30.03.2012 